\title{
Ectopic thyroid gland- presentation at childhood, adolescent and adult life
}

\author{
${ }^{1}$ Md. Sunny Anam Chowdhury, ${ }^{2}$ Mohshi Um Mokaddema, ${ }^{2}$ Tanzina Naushin, ${ }^{2}$ Simoon Salekin, \\ ${ }^{2}$ Nabeel Fahmi Ali, ${ }^{2}$ Fatima Begum, ${ }^{2}$ Sadia Sultana \\ ${ }^{1}$ Institute of Nuclear Medicine and Allied Sciences, Bogra \\ ${ }^{2}$ National Institute of Nuclear Medicine and Allied sciences
}

For correspondence: Dr. Md. Sunny Anam Chowdhury, Medical Officer, Institute of Nuclear Medicine And Allied Sciences, Post Box no- 60, Bogra- 5800, e-mail-drsunny43@gmail.com

\begin{abstract}
Ectopic thyroid is a rare entity that can appear at any age with different presentations. In this study we are reporting four cases of ectopic thyroid gland at different ages; two cases at childhood, one at adolescent and one at adult life. Among the two children, one having ectopic thyroid at the level of hyoid bone, presented with anterior neck swelling with no other symptom and another one having a lingual ectopic thyroid presented with features of hypothyroidism and obstructive features. The cases of adolescent and adult age are very rare cases of dual ectopic thyroid and ectopic thyroid tissue coexisting with normal thyroid gland respectively. Both of them presented with anterior neck swelling, with additional complaints of dysphagia and foreign body sensation by the adolescent patient. All the cases, ectopic thyroids were detected by Ultrasonogram and confirmed by radionuclide $\left.{ }^{99 \mathrm{~m}} \mathrm{Tc}\right)$ thyroid scan.
\end{abstract}

\section{INTRODUCTION}

Ectopic thyroid refers to all cases in which the thyroid gland is found in any location other than the normal anterior neck region between the second and fourth tracheal cartilage. It is the most frequent form of thyroid dysgenesis, accounting 48-61\% of the cases (1). Ectopic thyroid tissue can be found anywhere from foramen caecum to all along the normal decent path up to the normal cervical position of the thyroid gland as well as in the mediastinum and distant subdiaphragmatic areas (1-3). Prevalence of ectopic thyroid gland is about 1 per 100000-300000 people, rising to 1 per 4000-8000 thousands patients with thyroid disease $(1,2)$. Ectopic thyroid is most common in female, especially in Asian people. It may be presented in any age, from 5 
months to 40 years, but most common at younger ages (2). Here, few cases of ectopic thyroid glands are reported with their first presentation at childhood, adolescent and adult life.

\section{CASE REPORTS}

Case-1: A 4-years old boy presented with the history of swelling in upper anterior neck for 1.5 years (Figure-1, a). The size of the swelling was increasing rapidly for last one month. His father gave history of decreased appetite without any other symptoms. On physical examination, a small oval shaped, non-tender, firm palpable mass was found in mid upper neck that moved with deglutition. Thyroid hormone study revealed normal serum $\mathrm{FT}_{4}(12.5 \mathrm{pmol} / \mathrm{L})$ and TSH (3.17 $\mathrm{mIU} / \mathrm{L})$ level. Ultrasound scan showed no thyroid tissue in thyroid bed. The palpable swelling in upper mid anterior neck corresponded with a solid mass of about $18 \times 16 \times 10 \mathrm{~mm}$ at the level of hyoid bone having tissue texture same as thyroid gland. Radioisotope thyroid scan by $99 \mathrm{~m}$ Technetium $\left({ }^{99 \mathrm{~m}} \mathrm{Tc}\right)$ showed no radioactivity in normal thyroid bed suggesting absence of thyroid gland. There was an area of intense radiotracer concentration at the level of the palpable and sonographically detected mass (Figure-1, b).

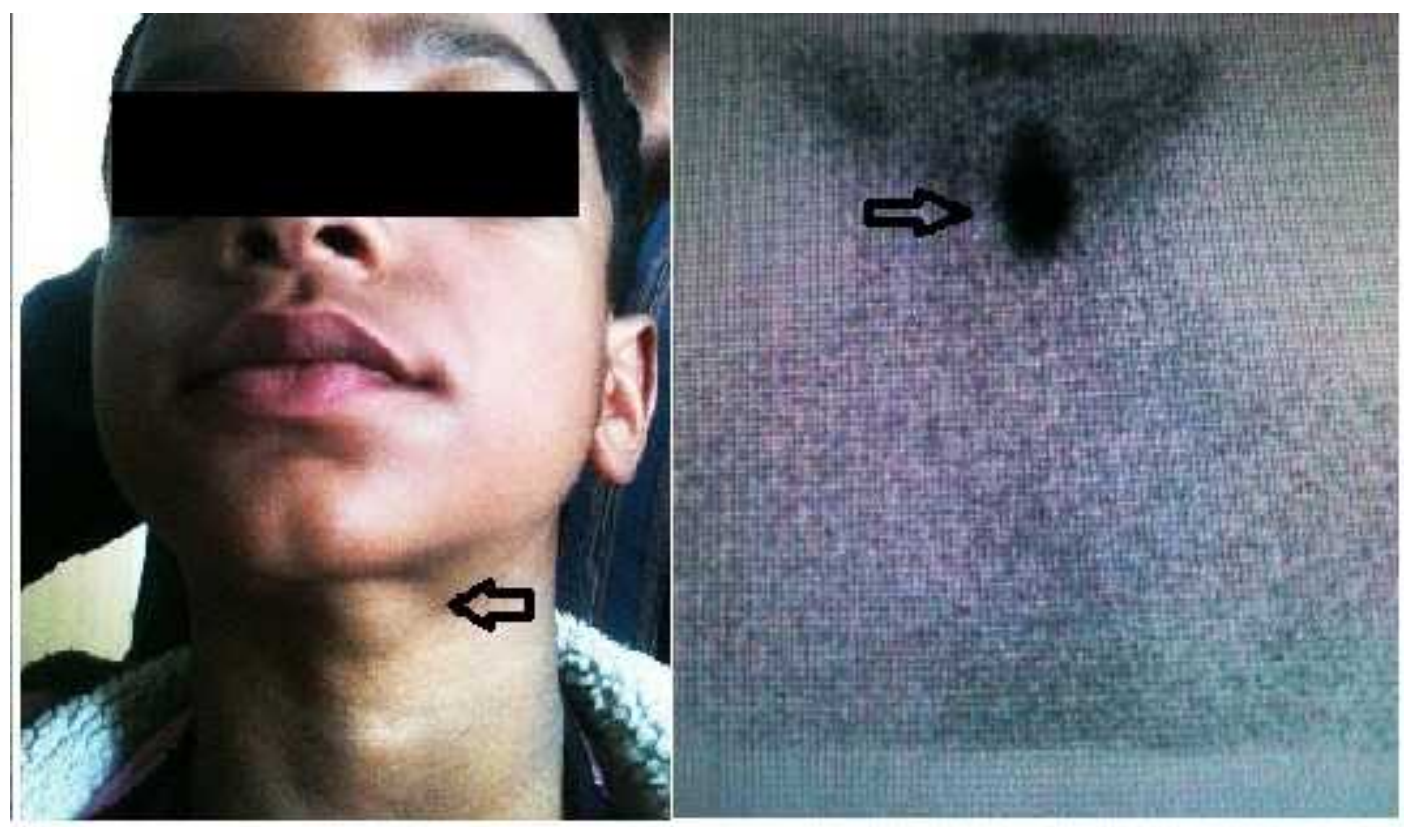

Figure 1(a): 4 years old boy presented with swelling in the mid upper neck (at the level of thyroid bone)
Figure 1 (b): 99mTc thyroid scan showing ectopic thyroid gland above the thyroid bed. 
Case-2: A 8-years old girl having low socio-economic status, presented with history of dysphonia, dysphagia, swelling of whole body, delayed growth and mental slowing. Her father also gave history of delayed development of milestones- sitting, standing, and talking. Her parents ignored physical developmental retardation of the baby. On physical examination, she was short statured, having coarse dry skin and her intelligence level seemed low. Thyroid hormone study revealed elevated TSH level $>75 \mathrm{mIU} / \mathrm{L}$ and low FT4 level $<0.30 \mathrm{pmol} / \mathrm{L}$. On ultrasound scan, no thyroid tissue was seen in thyroid bed. Rather a thyroid tissue like structure measuring about $8 \times 6 \mathrm{~mm}$ was seen at the level of the base of the tongue (Figure-2, a). ${ }^{99 \mathrm{~m}} \mathrm{Tc}$ thyroid scan showed no thyroid tissue in thyroid bed. Focal radiotracer concentration was seen to the base of the tongue (figure-2, b). Here amount of ectopic thyroid tissue was small enough to meet body requirement and leads to hypothyroidism.

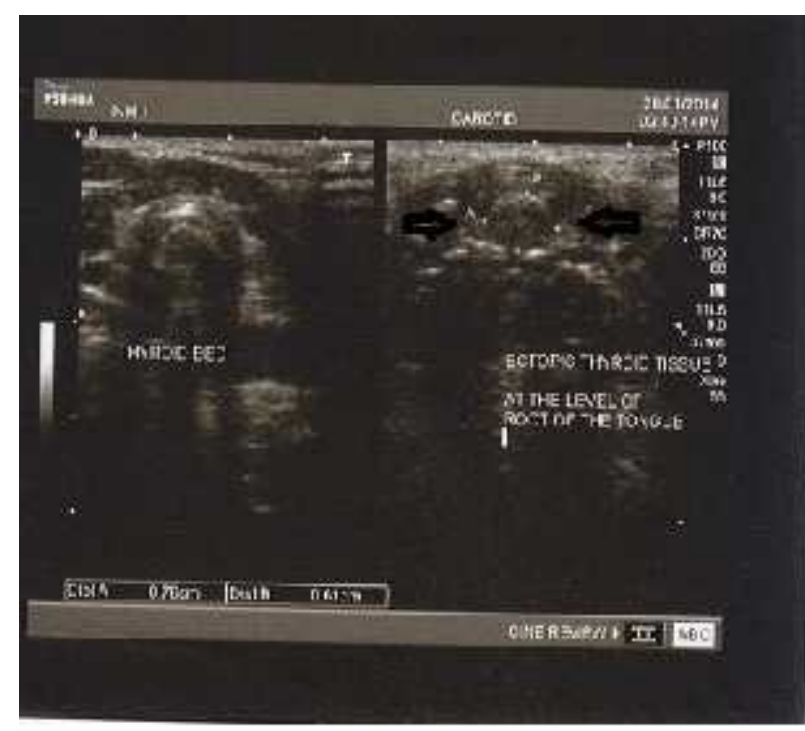

Figure 2 (a): Transverse ultrasonography of Neck showing no thyroid tissue in thyroid bed. A suspicious ectopic thyroid tissue at the level of the base of the tongue.

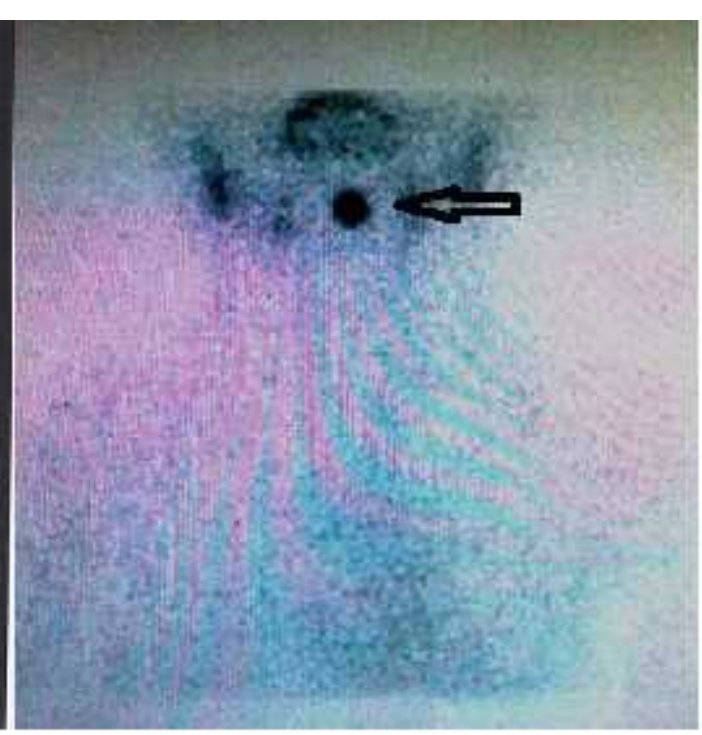

Figure 2 (b): ${ }^{99 \mathrm{~m}} \mathrm{Tc}$ Thyroid scan confirming lingual ectopic thyroid.

Case-3: A 13-years old female presented with swelling in front of the neck for 8 years with foreign body sensation in neck/ throat and difficulty in deglutition. The swelling was gradually increasing in size. On physical examination, a rounded, firm palpable mass was noted in upper mid anterior neck, which moved with deglutition. Biochemically, her serum levels of T3 (1.09 nmol/L), T4 (112.3 nmol/L) and TSH (3.61 mIU/L) were normal. Ultrasound scan showed no thyroid tissue in thyroid bed. The palpable mass in front of neck corresponded with an oval 
shaped mass having tissue texture same as thyroid tissue measuring about 29 x $14 \mathrm{~mm}$ above the thyroid bed. Another small mass tissue texture same as the previous one is seen at the base of the tongue measuring 13 x $10 \mathrm{~mm}$ (Figure-3, a). On radionuclide ( ${ }^{99 \mathrm{~m}} \mathrm{Tc}$ ) thyroid scan, no radiotracer concentration was seen in thyroid bed. Intense radiotracer accumulation was noted in the region of palpable mass in front of the neck above the thyroid bed. Another small area of radiotracer concentration (intensity less than the previous one) was seen at the level of the base of the tongue (Figure-3, b). The case was diagnosed as abnormal positions of both lobes of thyroid gland.

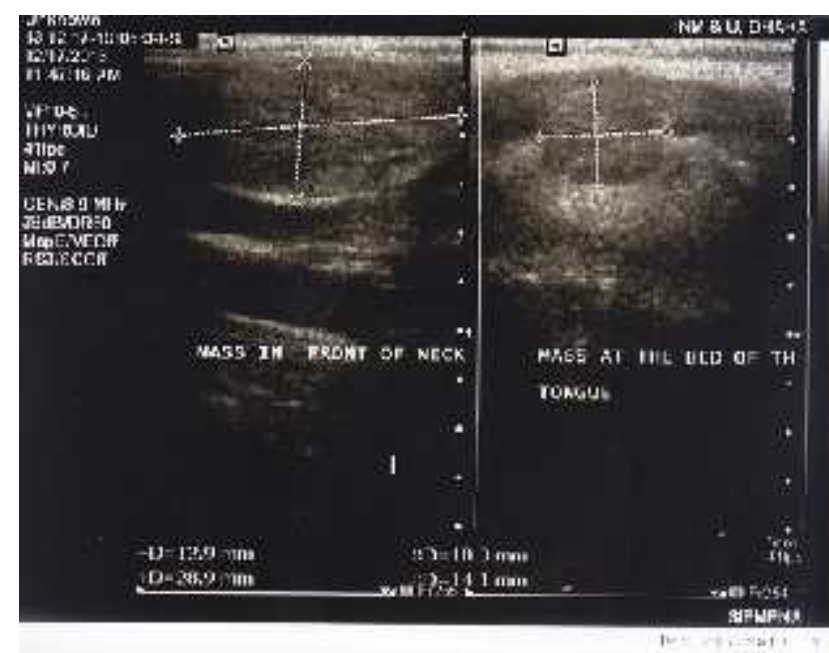

Figure 3 (a): Ultrasonography showing thyroid tissue like mass in front of the neck and at the base of the tongue.
Figure 3 (b): ${ }^{99 \mathrm{~m}} \mathrm{Tc}$ Thyroid scan confirming dual ectopic thyroid foci.

Case-4: A 22 years old female presented with swelling at the mid upper neck for 5 years which was initially small but gradually increasing in size (figure-4, a). On physical examination, thyroid gland was palpable in its normal position. An oval shaped, non-tender palpable mass was also found in mid upper anterior neck, which was initially diagnosed as thyroglossal cyst. Thyroid hormone study revealed euthyroid state (FT4 -14.9 pmol/L and TSH - 4.9 mIU/L level). On ultrasound scan, slightly enlarged thyroid gland was seen in its normal position with uniform parenchymal echotexture. An oval shaped slightly hypoechoic solid mass was also seen in midline at the level of hyoid bone corresponding to the palpable mass measuring $19 \times 15 \mathrm{~mm}$ (Figure-4,b and c). 


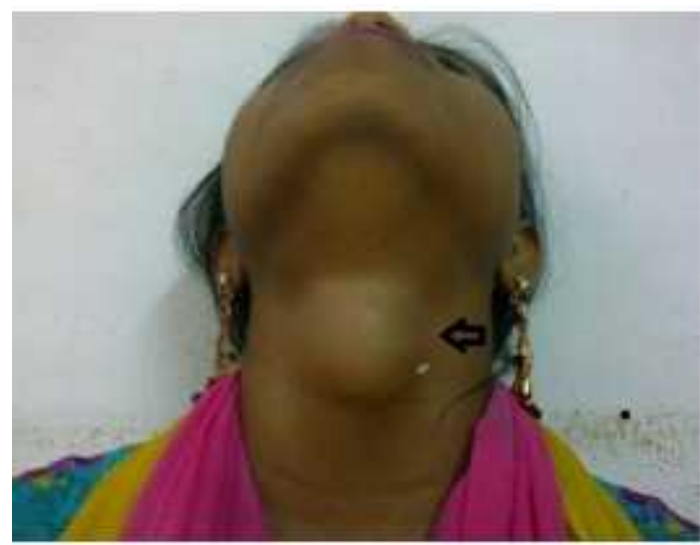

Figure 4 (a): A 22 years old female presented with swelling in the mid upper neck. Figure 4 (c): Normal Thyroid gland. Figure 4 (d): extra-thyroid solid mass above the thyroid gland (suspicious ectopic thyroid tissue co-existing with normal thyroid gland).

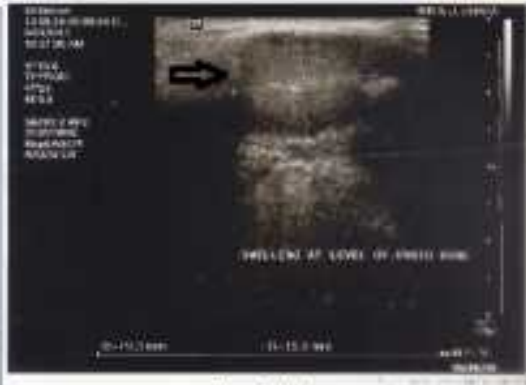

Fig. 4 (b)

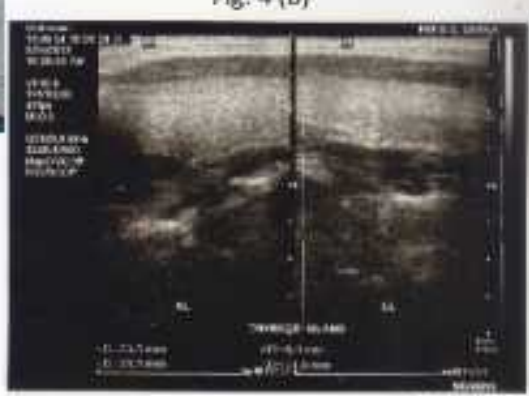

Fig. 4 (c)

99m Tc thyroid scan showed thyroid gland in its normal position along with accumulation of radiotracer at the region of visible and palpable mass initially thought of thyroglossal cyst. This case was diagnosed as ectopic thyroid tissue in thyroglossal duct along with normal thyroid gland.

\section{DISCUSSION}

Thyroid gland is the first endocrine gland that develops during embryogenesis on approximately $24^{\text {th }}$ day of gestation. It develops from pharyngeal endodermal diverticulum and descends creating a narrow channel called thyroglossal duct and reaches its final position in the neck by $7^{\text {th }}$ week of gestation $(2,4)$. Ectopic thyroid tissue is the result of a failure of migration of thyroid, not only along the route of thyroglossal duct but also in subdiaphragmatic organs, such as gallbladder and the adrenal glands (2). 
Table-I : Summary of characteristics of patients having ectopic thyroid gland

\begin{tabular}{|c|c|c|c|c|c|}
\hline Age & Sex & Presentation & USG & Scan & $\begin{array}{l}\text { Thyroid } \\
\text { function }\end{array}$ \\
\hline $\begin{array}{l}\text { Case-1 } \\
4 \text { years }\end{array}$ & Male & $\begin{array}{l}\text { Swelling in front of the neck } \\
\text { increasing the size rapidly. } \\
\text { Decreased appetite. }\end{array}$ & $\begin{array}{l}\text { No thyroid tissue in thyroid bed. } \\
\text { Thyroid tissue-like well defined } \\
\text { homogeneous, solid structure at } \\
\text { the level of hyoid bone. }\end{array}$ & $\begin{array}{l}\text { Thyroid gland was not } \\
\text { visualized in its normal } \\
\text { position. An intense area of } \\
\text { radiotracer concentration above } \\
\text { the thyroid bed. }\end{array}$ & Euthyroid \\
\hline $\begin{array}{l}\text { Case- } 2 \\
8 \text { years }\end{array}$ & Female & $\begin{array}{l}\text { Dysphagia. } \\
\text { Dysphonia. } \\
\text { Swelling of whole body. } \\
\text { Growth and mental } \\
\text { retardation. }\end{array}$ & $\begin{array}{l}\text { No thyroid tissue was seen in } \\
\text { thyroid bed. } \\
\text { A thyroid tissue like structure at } \\
\text { the level of the base of the } \\
\text { tongue. }\end{array}$ & $\begin{array}{l}\text { No thyroid tissue in thyroid } \\
\text { bed. } \\
\text { Focal radiotracer concentration } \\
\text { was seen posterior to the base } \\
\text { of the tongue. }\end{array}$ & Hypothyroid \\
\hline $\begin{array}{l}\text { Case- } 3 \\
13 \text { years }\end{array}$ & Female & $\begin{array}{l}\text { Swelling in front of neck. } \\
\text { Foreign body sensation in } \\
\text { throat and dysphagia. }\end{array}$ & $\begin{array}{l}\text { No thyroid tissue in thyroid bed. } \\
\text { An oval shaped thyroid tissue like } \\
\text { mass about } 29 \times 14 \mathrm{~mm} \text { above the } \\
\text { thyroid bed. } \\
\text { Another small thyroid tissue like } \\
\text { area seen at the base of the tongue } \\
\text { measuring } 13 \times 10 \mathrm{~mm} \text {. }\end{array}$ & $\begin{array}{l}\text { No radiotracer concentration } \\
\text { was seen in thyroid bed. } \\
\text { Intense radiotracer } \\
\text { accumulation was noted in } \\
\text { front of the neck above the } \\
\text { thyroid bed. } \\
\text { Another small area of } \\
\text { radiotracer concentration was } \\
\text { seen at the level of the base of } \\
\text { the tongue. }\end{array}$ & Euthyroid \\
\hline $\begin{array}{l}\text { Case-4 } \\
22 \text { years }\end{array}$ & Female & $\begin{array}{l}\text { Swelling in mid upper neck. } \\
\text { No other related complaints }\end{array}$ & $\begin{array}{l}\text { Slightly enlarged thyroid gland } \\
\text { was seen in its normal position } \\
\text { with uniform parenchymal } \\
\text { echotexture. } \\
\text { An oval shaped slightly } \\
\text { hypoechoic solid mass was seen } \\
\text { at the level of hyoid bone }\end{array}$ & $\begin{array}{l}\text { Thyroid gland was seen in } \\
\text { normal position with fairly } \\
\text { uniform radiotracer distribution } \\
\text { over the gland. Accumulation } \\
\text { of radiotracer is also seen in } \\
\text { front of neck above the level of } \\
\text { thyroid gland. }\end{array}$ & Euthyroid \\
\hline
\end{tabular}

We have summarised the reported cases in Table-I. Among the reported cases, two patients presented with ectopic thyroid tissue at the dorsum of tongue, locations of ectopic thyroid gland were on the midline along the path of descend in the rest of patients. In previous literatures, it was stated that lingual thyroid is the most common type, about $90 \%$ of the reported cases. Other sites of ectopic thyroid tissue include suprahyoid, infrahyoid, lateral aberrant thyroid, substernal, struma ovary, struma cordis, larynx, trachea, oesophagus, pericardium, diaphragm and branchial cyst. Rare cases of ectopic thyroid are described in parathyroid, cervical lymphnodes, submandibular gland, duodenal mesentery, heart, ascending aorta, thymus, duodenum, gallbladder, stomach bed, pancreas, porta hepatis, fallopian tube, uterus and vagina (1, 5). 
Among our cases, one female 13 years patient had dual thyroid ectopia- location of one part was at lingual region and another part was located at the level of hyoid bone. Abnormal position of two lobes of thyroid at different level is a very rare entity. Similarly ectopic thyroid tissue coexisting with a normal thyroid gland is seldom found. Very few cases of dual thyroid ectopia have been reported in world literature. In an extensive review of literature, the mean age of these patients was 15 years, more common in females with a F: M ratio of 1.25:1. In almost all of these patients one site of ectopy was at lingual or sublingual region. The second most common site of thyroid ectopia was at subhyoid or suprahyoid level $(2,4,6)$.

Symptoms are usually related to size and location of the ectopic gland as well as associated endocrine dysfunction. The chief complaint of majority of our patients was swelling in front of the neck. One of them presented with associated decreased appetite. Patient with dual thyroid ectopia had foreign body sensation in throat and dysphagia. The unfortunate 8 years old girl (case-2) having lingual thyroid presented with obstructive features along with features of hypothyroidism; dysphonia, dysphagia, swelling of whole body, delayed growth and mental slowness. She had also history of delayed development of milestones- sitting, standing, talking, which was ignored by her parents. When she was sent to us we found her clinically as short stature, having coarse dry skin, seemed to be with low intelligence level. Biochemically she was in hypothyroid state. Among the four cases she had smallest amount of thyroid tissue measuring $8 \times 10 \mathrm{~mm}$. It was reported that, in lingual thyroid, clinical manifestations peak at a mean age of 40 years with two statistical peaks at the ages of 12.5 and 50 years. Common symptoms are cough, pain, dysphagia, dysphonia, dyspnoea and haemorrhage. Large masses can be present with airway obstruction and stridor in children, while one third of patients have evidence of hypothyroidism. Sleep apnoea and respiratory obstruction in adult patients with lingual thyroid have also been reported (1). Sublingual or pre-laryngeal ectopic thyroid commonly presents as an anterior neck mass above, below or at the level of the hyoid bone which is usually painless, gradually increasing in size, and may move with swallowing as we found in our cases. Characteristically, the mass had smooth margins and is soft in consistency, mobile and nontender (1). The symptom of dual ectopic thyroid and ectopic thyroid tissue co-existing with normal thyroid gland varies from asymptomatic to anterior midline neck swelling. Biochemically one half of the patients are euthyroid and the rest are hypothyroid $(6,7)$. Our patient with dual thyroid ectopia and ectopic thyroid co-existing with normal thyroid gland showed euthyroid 
state. Children mainly present with features of hypothyroidism. Thyroid ectopy is present in $24 \%$ of children with primary non-goitrous hypothyroidism. Ectopic thyroid glands in infants and young children who suffer from failure to thrive and mental retardation are often detected during routine screening and work-up for hypothyroidism. On the other hand, presentation with clinical features of hyperthyroidism is less common (1).

High-resolution ultrasound examination plays a valuable role in diagnosis, showing site and size of ectopic thyroid tissue and differentiates between cystic and solid masses. Radionuclide thyroid scan can detect all ectopic foci of thyroid in the body, thus becomes most important diagnostic tool to detect ectopic thyroid (2). Ultrasonographic scan was used in all of our cases as initial assessment, specially in patients presenting with neck mass and ectopic thyroid glands were

confirmed by ${ }^{99 m}$ Tc thyroid scan. Besides these, computed tomography (CT) and magnetic resonance imaging (MRI) may help in evaluating the extension and location of ectopic thyroid tissue. Fine needle aspiration cytology (FNAC) helps in confirming diagnosis of ectopic thyroid as well as differentiates between a benign and malignant lesion $(1,2)$. In our cases we failed to collect FNAC findings as their referring physicians were not interested to do so.

The management of ectopic thyroid tissue depends on size of the mass, local symptoms, the patient's age, state of the thyroid gland and related complications. No treatment is required in asymptomatic and euthyroid patients, but they should be followed up and looked for any complications. Patients with raised TSH with swelling should be put on replacement therapy with thyroid hormone which can cause slow reduction of the size of the mass. In our reported cases, we found one case in hypothyroid state, levothyroxine replacement has been started. When medical treatment fails or there are obstructive symptoms or hemorrhage or suspicion of malignancy then surgery should be considered. However, $70-90 \%$ of patients have no functioning thyroid tissue besides the ectopic thyroid, so extreme caution must be taken; removal of the only functioning thyroid tissue will result in permanent hypothyroidism $(1,3,6)$.

\section{CONCLUSION}

Most cases of ectopic thyroid are asymptomatic but hypothyroidism may occur in few cases of them. If it is not properly diagnosed and treated accordingly normal growth and mental development may be hampered in children. Periodic follow-up is necessary to ensure proper 
management. Patients with ectopic thyroid need careful diagnosis, treatment and regular followup.

\section{REFERENCES}

1. Ibrahim NA, Fadeyibi IO. Ectopic thyroid: etiology, pathology and management. Hormones 2011; 10(4):261-69

2. Noussios G, Anagnostis P, Goulis DG, Lappas D, Natsis K. Ectopic thyroid tissue: anatomical, clinical and surgical implications of a rare entity. European Journal of Endocrinology 2011;165: 375-82

3. Babazade F, Mortazavi H, Jalalian H, Shahvali E. Thyroid tissue as a sub-mandibular mass: a case report. Journal of Oral Science 2009; 51(4):655-57

4. Sood A, Kumar R. The ectopic thyroid gland and the role of nuclear medicine techniques in its diagnosis and management. Hell J Nucl Med 2008;11(3):168-71

5. Awal MA, Ansari SM, Rahman MH, Siddique AB, Chowdhury SA. Importance of regular bio-chemical follow-up of patients having ectopic thyroid- study of 7 cases. Bangladesh J Nucl Med 2011; 14(2): 131-35

6. Jousal CP, Ramaniraj M. Dual ectopic thyroid - A case report of a very rare disease. Online Journal Otolaryngology 2012; 2(2) Accessed on 26 Feb 2014,

7. Zheng W, Tan J, Liu T. Coexistence of non-functional ectopic thyroid tissue and a normal thyroid: A case report. Experimental Therapeutic Medicine 2013; 6: 1059-61 